\title{
ХИЙМЭЛ ДАГУУЛЫН МЭДЭЭ БОЛОН ЦАГ УУРЫН АЖИГЛАЛТЫН МЭДЭЭНД СУУРИЛСАН МОНГОЛ ОРНЫ БИО- УУР АМЬСГАЛЫН ЧАДАВХИЙН УНЭЛГЭЭ
}

\author{
О.Мөнхуулам ${ }^{* 1}$, Э. Авирмэд ${ }^{1}$, Д.Сайнбаяр ${ }^{1}$ \\ ${ }^{I}$ ШУА-ийн Газарзүй-Геоэкологийн хүрээлэн, Монгол улс \\ * Цахим шуудан: munkhdulamo@gmail.com
}

\section{ХУРААНГУЙ}

ЭнэхүҮ судалгааны ажлын гол зорилго нь хиймэл дагуулын болон изаг уурын ажиглалтын мэдээнд үндэслэж, Монгол орны био-уур амьсгалын чадавхийг үнэлэх явдал юм. Тус судалгаанд Селянинов, Иванова, Шашко нарын боловсруулсан чийг-дулааны коэффициент, уур амьсгалын биологийн үр ашгийн индекс, био-уур амьсгалын чадавхийн үнэлгээний арга зүйг ашигласан. Дүн шинжилгээнд МОДИС хиймэл дагуулын 2000-2014 оны 01 дүгээр сараас 12 дугаар сар хүртэлх хугацааны 1 км-ийн нарийвчлалтай 16 хоногийн дундаж 11, 16 сувгийн бүтээгдэхүYн (MOD11, MOD16), TRMМ хиймэл дагуулын 2000-2014 оны 0.25 градусын нарийвчлалтай сарын нийлбэр хур тунадасны мэдээ болон иаг уурын стани, харуулын 20002014 оны сарын дундаж агаарын температурын мэдээ болон мөн хугаиааны сарын дундаж агаарын дутагдал чийгийн мэдээг ашигласан. Дүн иинжилгээний үр дүнд Монгол орны чийг-дулааны коэффициент, уур амьсгальын биологийн үр ашгийн индекс, био-уур амьсгальын чадавхийн орон зайн тархалтын зургуудыг боловсруулсан. Судалгааны үр дүнгээс үзэхэд хиймэл дагуулын мэдээ, иаг уурын ажиглалтын мэдээлэлд үндэслэн газарзүйн мэдээллийн систем болон тандан судалгааны технологийг ашиглан био-уур амьсгалын чадавхийг үнэлэх боломжтой болох нь харагдаж байна. Дурдсан 3 арга зүйг ашиглан орон зайн тархалтын зураглал боловсруулснаар бүс нутгийн түвшний асуудльг уур амьсгальн хандлагын ҮҮднээс зөв ялган тогтоох боломжтойг илтгэх ба байгаль, цаг уурын нөхиөлөөс шууд хамааралтай манай орны нийгэм- эдийн засгийн гол салбар болох хүн ам, мал аж ахуй, газар тариалангийн салбарын төлөвлөлт, менежментийн үйл ажиллагаа зохион байгуулахад иаг хугаиаа хэмнэсэн, иинжлэх ухааны үндэслэлтэй шийдвэр гаргах боломж бүрдэж байна.

Түлхүүр үгс: Чийг- дулааны коэффищиент, биологийн үр ашгийн индекс, био-уур амьсгалын чадавх, хиймэл дагуулын мэдээ;

\section{ОРШИЛ}

Тус хүрээлэнгийн Физик газарзүйн салбар нь 2017 оноос “Монгол орны байгалийн бүсүүдийн ландшафтын экологийн чадавхийн үнэлгээ” төслийн ажлыг хэрэгжүүлж хэд хэдэн зорилт дэвшүүлсний нэг нь Монгол орны биоуур амьсгалын чадавхийг үнэлж, зураглах ажил байсан. Байгаль, цаг уурын нөхцөлөөс 
шууд хамааралтай [1] Монгол орны нийгэм- эдийн засгийн гол салбар болох хүн ам, мал аж ахуй, газар тариалангийн салбарын төлөвлөлт, менежментийн үйл ажиллагаа зохион байгуулахад биоуур амьсгалын нөхцлийг харгалзан Үзэх нь чухал ач холбогдолтой. Өөрөөр хэлбэл, уур амьсгалын нөхцөл нь амьд организмын гадаад байдал болон дотоод физиологийн үйл явцад олон талын нөлөө үзүүлнэ [2]. Дулааны тэнцвэртэй байдал нь амьд организмд тааламжтай нөхцлийг бүрдүүлдэг бол хэт халуун, эсвэл хэт хүйтэн орчинд физиологийн систем түгшүүртэй байх нь мэдээж. Гадаад орчны голлох үзүүлэлтүүдийн эрчим, үйлчлэх хугацаанаас шалтгалж организмын

\section{СУДАЛГААНЫ АРГА ЗУЙ}

Судалгаанд Селянинова (1937, 1999), Иванова (1999), Шашко (2005) нарын үнэлгээний арга зүйг ашигласан ба арга зүйн бүдүүвчийг Схем 1-д үзүүлэв.

Селянинова (1999)-ийн боловсруулсан томьёогоор (1) ургамлын ургалтын хугацааны чийгийн зэрэг болон чийгдулааны коэффициентыг тооцов.

$$
\text { чДК }=\frac{\sum P}{\left[0.1 \sum T_{>X} o_{C}\right]}
$$

ЧДК - чийг-дулааны коэффициент

$P$ - хур тунадасны нийлбэр, мм

$\sum T_{>X}$-сарын дундаж агаарын

температурын нийлбэр, ${ }^{0} \mathrm{C}$

$x$ - температурын босго утга $\left(\mathrm{x} \geq 10^{\circ} \mathrm{C}\right)$

Чийг хангамжийн зэрэг нь дараах хязгааруудын хооронд ангилагдана. Үүнд:

ЧДК $<0.4-$ нэн хуурай

$0.4 \leq$ ЧДК $<0.5$ - хуурай

$0.5 \leq$ ЧДК $<0.7$ - гандуу

$0.7 \leq$ ЧДК $<1.0-$ чийг хангамж дутмаг

$1.0 \leq$ ЧДК $<2.0$ - чийг хангамж хүрэлцээтэй

ЧДК>2.0-илүүдэл чийгтэй

Н.Н.Иванова-ийн чийг хангамжийн амьдрах физиологийн таатай нөхцлийг хангахад шаардагдах зардлын хэмжээ харилцан адилгүй байна [2]. Монгол орны био-уур амьсгалын чадавхийн үнэлгээнд Г.Т. Селянинова (1937)-ийн чийг-дулааны коэффициент [3], Н.Н. Иванова (1999)ийн уур амьсгалын биологийн үр ашгийн индекс [4], Д.И. Шашко (2005)-ийн биоуур амьсгалын чадавхийн үнэлгээний арга зүй болон дэлхийн ажиглалтын хиймэл дагуулын мэдээг цаг уурын станц, харуулын мэдээтэй хослуулан дүн шинжилгээ хийж, орон зайн тархалтыг тооцож үр дүнг Физик газарзүйн салбарын 2017 оны 8-9 дүгээр сард явуулсан хээрийн судалгаагаар баталгаажуулсан болно.

коэффициент нь жилийн хур тунадасны хэмжээ болон ууршилтын харьцаагаар тодорхойлогдох ба жилийн нийлбэр ууршилт нь сар бүрийн ууршилтын хэмжээгээр тодорхойлогдоно [5].

$$
E=0.0018(25+t)^{2} *(100-f)
$$

$t$ - сарын дундаж агаарын температур

$f$ - сарын дундаж агаарын харьцангуй чийг

Уур амьсгалын биологийн үр ашиг (бүтээмж)-ийн индексийг (индекс биологической эффективности-) дараах томьёогоор тодорхойлсон.

$$
Б Y A И=\left(0.01 \sum_{>10}\right) * K Y
$$

БҮАИ - уур амьсгалын биологийн үр ашгийн (бүтээмжийн) индекс

$\Sigma_{>10}^{T}-10^{\circ} \mathrm{C}$-аас дээш сарын дундаж температурын нийлбэр

$K У$ - чийг хангамжийн коэффициент

Чийг хангамжийн коэффициент (КУ) нь жилийн нийлбэр хур тунадсыг жилийн ууршилттай харьцуулсан харьцаагаар тодорхойлогдоно. 


$$
K \mathrm{Y}=\frac{P}{E_{o}}
$$

$P$ - жилийн нийлбэр хур тунадас, мм

$E_{0}$ - (2) томьёогоор тодорхойлогдсон ууршилт

Био-уур амьсгалын чадавхийг үнэлэхэд Д.И.Шашко (2005) боловсруулсан томьёог ашигласан [6].

$$
\text { БКП }=K p(k y) \frac{\sum t_{>10}^{0}}{\sum t_{a k \text { (баз })}}
$$

БКП - био-уур амьсгалын чадавх

$K p(k y)$ - агаар мандал дахь чийгийн жилийн өсөлтийн коэффициент
$\Sigma t_{\gg 10}^{0}-10^{\circ} \mathrm{C}$-аaс дээш сарын дундаж температурын нийлбэр

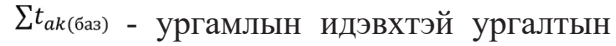
хугацаан дахь өдер тутмын дундаж температурын нийлбэр

$$
K p(k y)=\lg \left(20 K_{y \in i}\right)
$$

$K_{\text {увл }}-$ жилийн нийлбэр агаарын чийгийн коэффициент

$$
\mathrm{K}_{\text {увл }}=\frac{\mathrm{P}}{\sum \mathrm{d}}
$$

P - нийлбэр хур тунадас, мм

$\sum$ d - сарын дундаж агаарын дутагдал чийгийн нийлбэр

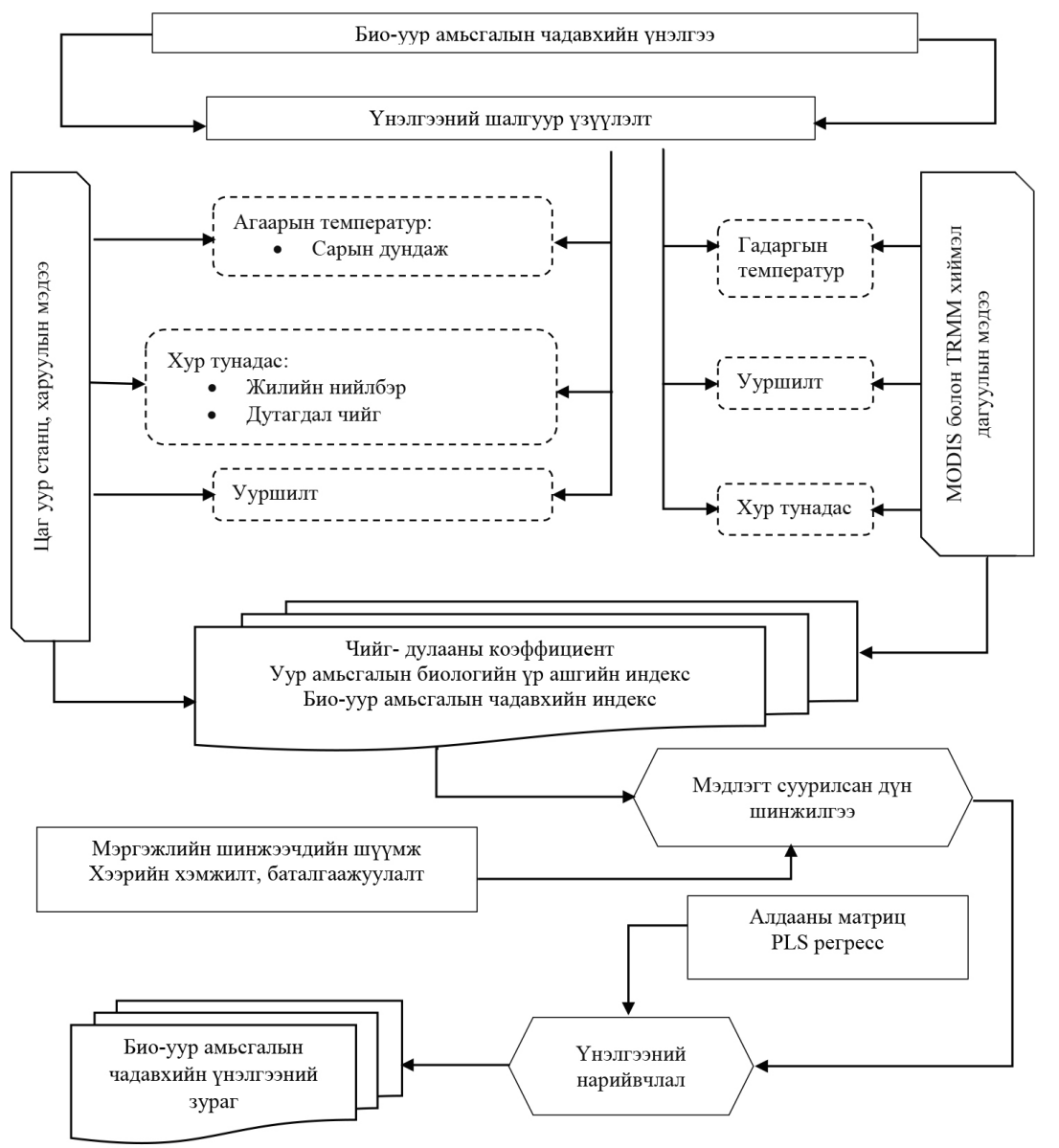

Схем 1. Био-уур амьсгалын чадавхийн үнэлгээний аргазүйн бүдҮҮвч

$$
-7 \text { - }
$$




\section{СУДАЛГААНЫ МАТЕРИАЛ}

Судалгаанд газарзүйн ялгаатай байршил дахь цаг уурын станц, харуулын хэмжилтийн 2000-2014 оны тоон мэдээ, мөн хугацааны MODIS (Moderate Resolution Imaging Spectroradiometer) хиймэл дагуулын гадаргын температур, ууршилт, TRMM (Tropical Rainfall Measure Mission) хиймэл дагуулын хур тунадасны мэдээг ашигласан. Цаг уурын станц, харуул дээр бүртгэгдсэн мэдээ нь олон тооны харилцан уялдаа бүхий багаж, нэгдсэн арга зүйг ашигладаг учир био- уур амьсгалын загваруудад ашиглах мэдээллийг олж авах үндэслэл болдог [7]. Мөн цаг уурын станц, харуулын хэмжилтийн бодит мэдээ нь орон нутгийн онцлог шинж чанаруудыг нарийн тусгадаг. Судалгаанд цаг уурын станц, харуулын ажиглалт, хэмжилтийн доор дурдсан өгөгдлүүдийг ашигласан. Үүнд:

- Сарын дундаж агаарын температур

- Жилийн нийлбэр хур тунадас

- Жилийн нийлбэр ууршилт

\section{Мэдээ боловсруулах үе шат}

Цаг хугацааны тасралтгүй цуваа үүсгэж, боловсруулалт дүн шинжилгээ хийх үйл явц бэлтгэл, боловсруулах, баталгаажуулах гэсэн 3 үе шатнаас бүрдсэн.

Бэлтгэл үе шатанд дараах 3 төрлийн мэдээллийг холбогдох эx сурвалжаaс бүрдүүлж, анхан шатны боловсруулалтыг хийсэн. Үүнд:

1. Америкийн үндэсний сансар судлалын агентлаг (NOAA)-ийн мэдээллийн төв сервер (http://e4ft101. cr.usgs.gov)-ээс Монгол орны нийт нутаг дэвсгэрийг хамарсан 4 багана, 2 мөрийн нийт 7 торлолын (h23v03; h23v04; h24v03; h24v04; h25v03; h25v04; h26v04;) 2000-2014 оны сарын дундаж гадаргын температур, жилийн дундаж ууршилтын мэдээг татсан. Тус мэдээний нэг торлолын хэмжээ нь 10х10 градус, 1 км-ийн орон зайн нарийвчлалтай, хоногт 4 удаа хэмжилт
- Сарын дундаж агаарын дутагдал чийг

Эх газрын эрс тэс уур амьсгалтай Монгол орны хувьд цаг уурын элементүүд нь богино зайд хувьсан өөрчлөгддөг онцлогтой [8], өөр хоорондоо алслагдсан 300 гаруй станц, харуулын хэмжилтийн цэгийн хүрээнд орон зайн тархалтыг тооцож орон зайн ялгаатай био-уур амьсгалын чадавхийн үнэлгээний зураг гаргах боломж хязгаарлагдмал юм. Тиймээс бид цаг уурын станц, харуулын мэдээ болон хиймэл дагуулын мэдээний хоорондын хамаарал, уялдаа холбоог тодорхойлж цаг уурын элементүүдийн сар, жилийн явц, өөрчлөлт, хандлага дээр үндэслэн био-уур амьсгалын чадавхийг үнэлж, орон зайн тархалтыг тооцох зорилт тавьсан. Судалгааны талбайн хамрах хүрээ, нарийвчлал, цаг хугацааны давтамжийн онцлогоос хамаарч MODIS болон TRMM хиймэл дагуулын мэдээг ашигласан.

хийдэг $(01: 30 ; 10: 30 ; 13: 30 ; 22: 30$ орон нутгийн цагаap), Sinusoidal проекцтой, HDF өргөтгөлтэй багц мэдээ болон метадата агуулсан XML файлыг багтаадаг. MODIS MRT программыг ашиглаж Sinusoidal координатын системийг датум WGS84, UTM N48 систем рүY хөрвүүлж, Монгол орны хэмжээнд нэгтгэх (mosaic), улсын хилээр таслах (clip), температурын дижитал тоон утгыг Кельвиний нэгжид, ууршилтын дижитал тоон утгыг мм-ийн нэгжид хөрвүүлэх (raster calculator), чанарын шалгалтын зураг боловсруулах (extract sub dataset), тоон матриц үүсгэх (Raster to ASCII), температур, ууршилтын хэт их, бага утгыг олох (1st, 3rd quartile), алдаатай утгыг олох (IsNull), зөрүY утгын тооцох (Raster Calculator), гадаргын температур, ууршилтын мэдээг нөхөх (SetNull, Con) зэрэг тооцоо, боловсруулалт хийсэн. 
2. Хур тунадас бол усны эргэлтийн чухал хэсэг, тодорхойгүй хугацаанд ажиглагдах бөгөөд ялангуяа зуны улиралд огцом нэмэгддэг. Хур тунадасны хэмжээ, тархалтыг оновчтой тодорхойлох бодит арга бол сансрын удирдлагат хэмжих дагуулыг ашиглах. Сүүлийн жилүүдэд агаар мандлын температур, усны уурын хэмжээг тодорхойлохдоо туйлын замналтай цаг уурын Америкийн NOAA, Европын EUMETSAT/MetOp, Хятад, Оросын хиймэл дагуулуудыг түгээмэл ашиглаж байгаа хэдий ч судлаачдын хувьд эдгээр хиймэл дагуулын мэдээллийг ашиглах боломж хязгаарлагдмал байдаг. Харин TRMM нь хур бороо судлан шинжлэхээр бүтээгдсэн анхны хиймэл дагуул бөгөөд өөртөө цаг агаарын радар агуулдаг. Тус хиймэл дагуулыг 1997 онд АНУ (NASA) болон Японы сансрын судалгааны агентлаг (JAXA) хамтран хөөргөсөн, агаар мандалд ялгаруулсан богино долгионы эрчмийг хэмжих замаар цаг уур, уур амьсгалын судалгаa болон хур тунадсыг хэмжих зориулалттай. Энэ судалгаанд TRMM хиймэл дагуулын $0.25 * 0.25$ градусын торлол бүхий *.txt өргөтгөлтэй, 20002014 оны сарын нийлбэр хур тунадасны мэдээг төв серверээс (https://pmm.nasa.gov/ trmm)-aас татаж, зэргэлдээ хөршийн аргаар (Nearest Neighbor Samplying) интерполяц хийх замаар растер бүтэцтэй мэдээг үүсгэж дүн шинжилгээнд ашигласан.

3. Монгол орны нутгаар тархан байрлах 313 цаг уурын станц, харуулын (станц 121, харуул 192) 2000-2014 оны сарын дундаж агаарын температур, сарын дундаж агаарын дутагдал чийг, сарын нийлбэр хур тунадасны мэдээг боловсруулж хиймэл дагуулын мэдээтэй харьцуулсан дүн шинжилгээ хийхэд ашигласан.

Боловсруулалтын үе шат: Агаарын температур (Та) нь энергийн тэнцвэрт байдалд чухал үүрэг гүйцэтгэдэг бөгөөд тариалангийн ууршилтын тооцоо, усзүй болон уур амьсгалын өөрчлөлтийн зэрэг төрөл бүрийн ХБО-ны загварууд болон программуудын үндсэн оролт нь болдог. Цаг уурын станцууд агаарын температурыг газрын гадаргаaс дээш 2 метрийн өндөрт хэмждэг. Цаг уурын хэмжилтүүд нь тодорхой байршлуудад зориулсан нарийвчилсан салангид агаарын температурын мэдээллийг өгдөг боловч өргөн уудам газар нутагт орон зайн олон төрлийг тодорхойлох чадвар хязгаарлагдмал байдаг [11]. Ихэнх сүлжээ цаг уурын станцуудын орон зайн тархалт жигд биш бөгөөд газрын гадаргын нөхцөл, хэв шинжээс хамаарч орон зайн хувьд тасралтгүй агаарын температурын мэдээг олж авахад хүндрэлтэй байдаг. Тэгвэл AVHRR (Advanced Very High Resolution Radiometer) болон MODIS (Moderate Resolution Imaging Spectroradiometer) зэрэг хиймэл дагуулын мэдээнээс их хэмжээний газар нутгийг хамарсан агаарын температурыг тархалтын мэдээг орон зайн хувьд нарийвчлалтайгаар илэрхийлэх боломжтой харуулсан олон судалгааны ажлууд хийгдсэн байна [12]; [13]; [14]; [15]; [16]. МОДИС хиймэл дагуулын газрын гадаргын температурын мэдээнд температурын градиентийн аргаар залруулга хийх замаар газрын гадаргын температурын мэдээг агаарын температурын утга руу шилжүүлэх боломж байдаг байна. ДИС6 МОДИС хиймэл дагуулын хөрсний гадаргын температурын мэдээг агаарын температурын утга руу шилжүүлэхэд Colombi (2007) нарын боловсруулан дараах шугаман тэгшитгэлийг ашигласан [12].

$$
\begin{array}{ll}
\mathrm{Ta}=0.649 * \mathrm{LST}+1.4036 & \text { (Өдрийн) } \\
\mathrm{Ta}=0.791 * \mathrm{LST}+2.7691 & \text { (Шөнийн) }
\end{array}
$$

Та- агаарын температур

LST- MOДИС хиймэл дагуулын газрын гадаргын температур 


\section{YР ДУН}

МОДИС хиймэл дагуулын ууршилт, TRMM хиймэл дагуулын хур тунадасны мэдээ болон цаг уурын станц, харуулын агаарын температур, дутагдал чийгийн мэдээг ашиглан чийг-дулааны коэффициент, уур амьсгалын биологийн үр ашгийн индекс, уур амьсгалын биологийн чадавх зэрэг үзүүлэлтийг Монгол орны хэмжээнд тооцож, орон зайн тархалтын зургийг анхдагч байдлаар боловсруулав. Тооцооллын аргаар гаргасан тархалтын зургийн үнэмшил, нарийвчлалыг шалгахад мэдрэмжийн үнэлгээний аргыг олон хувьсагчийн регрессийн аргатай хослуулан ашигласан. Үнэлгээний ерөнхий нарийвчлал $84.0 \%$.

\section{Г.Т.Селянинова}

боловсруулсан

(1999)-ийн чийг-дулааны коэффициентийн томьёо (1)-оор тооцоо хийж үзэхэд Монгол орны нутаг дэвсгэрийн $7.1 \%$ нь хэт хуурай, 20\% нь хуурай, $12.1 \%$ нь гандуу, 14.4\% нь чийг дутмаг, $18.8 \%$ нь чийг хүрэлцээтэй, $12 \%$ нь чийглэг, $15.6 \%$ нь илүүдэл чийгтэй гэсэн ангилалд тус тус хамрагдаж байна (Хүснэгт 1, Зураг 1).

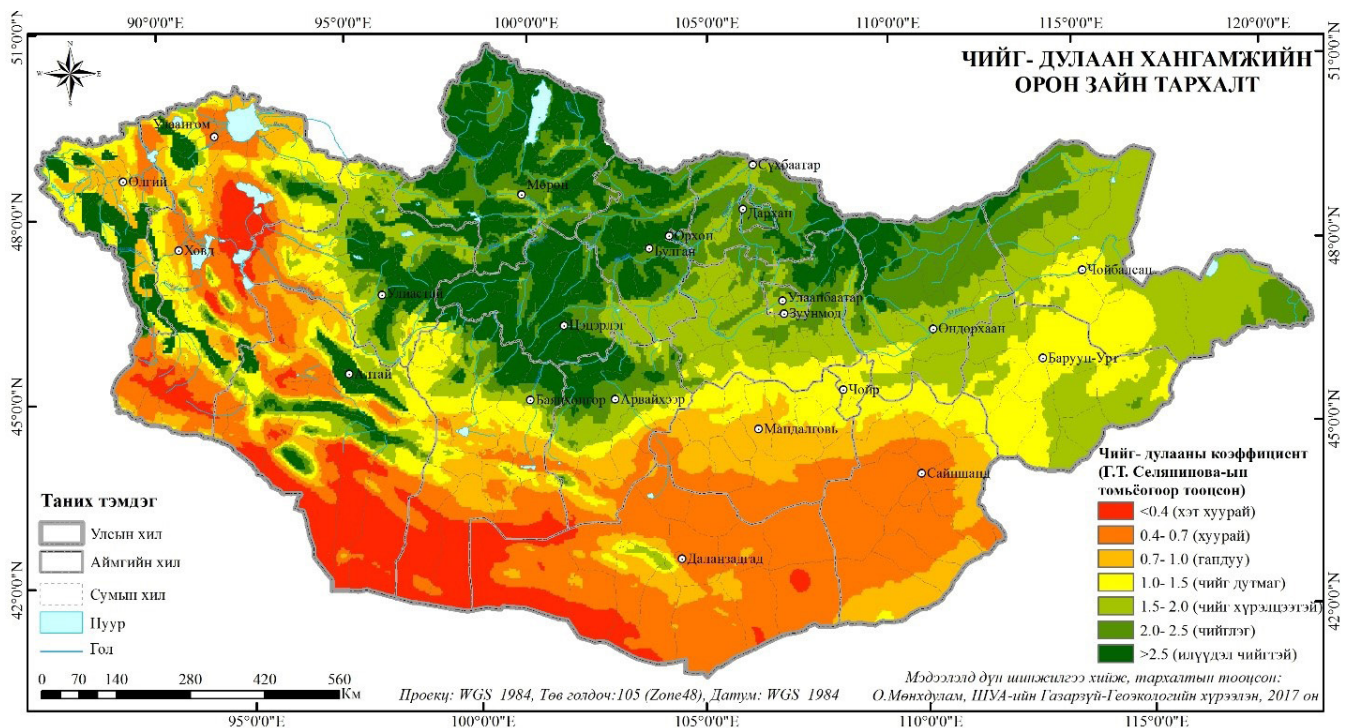

Зураг 1. Чийг- дулаан хангамжийн орон зайн тархалт

Хүснэгт 1. Чийг- дулааны коэффиииентийн орон зайн хуваарилалт

(Г.Т. Селянинова-ийн томьёогоор тооисон үр дүн)

\begin{tabular}{|c|c|c|c|}
\hline \multirow{2}{*}{$\begin{array}{c}\text { Чийг-дулааны } \\
\text { коэффициент }\end{array}$} & Чийг хангамжийн & \multicolumn{2}{|c|}{ Талбай } \\
\cline { 3 - 4 } & зэрэг & км $^{2}$ & $\%$ \\
\hline$<0.4$ & Хэт хуурай & 110690.9 & 7.1 \\
\hline $0.4-0.7$ & Хуурай & 312689.9 & 20.0 \\
\hline $0.7-1.0$ & Гандуу & 190204.5 & 12.1 \\
\hline $1.0-1.5$ & Чийг дутмаг & 225463.1 & 14.4 \\
\hline $1.5-2.0$ & Чийг хүрэлцээтэй & 295075.6 & 18.8 \\
\hline $2.0-2.5$ & Чийглэг & 187346.5 & 12.0 \\
\hline$>2.5$ & Илүүдэл чийгтэй & 244529.4 & 15.6 \\
\hline
\end{tabular}


Н.Н.Иванова (1999)-ийн боловсруулсан уур амьсгалын биологийн үр ашгийн (бүтээмжийн) индексийн томьёо (3)г ашиглан тооцоо хийж үзэхэд Монгол орны нийт нутаг дэвсгэрийн $5.9 \%$ нь 15 хувиас бага бүтээмжтэй, $24.6 \%$ нь $15-30$ хувийн бүтээмжтэй, $18.8 \%$ нь 30 -
45 хувийн бүтээмжтэй, $14.6 \%$ нь 45 60 хувийн бүтээмжтэй, $18.1 \%$ нь 60-75 хувийн бүтээмжтэй, $12.9 \%$ нь 75-90 хувийн бүтээмжтэй, $5.1 \%$ нь 90-өөс дээш хувийн бүтээмжтэй гэсэн тооцоо гарч байна (Хүснэгт 2, Зураг 2).

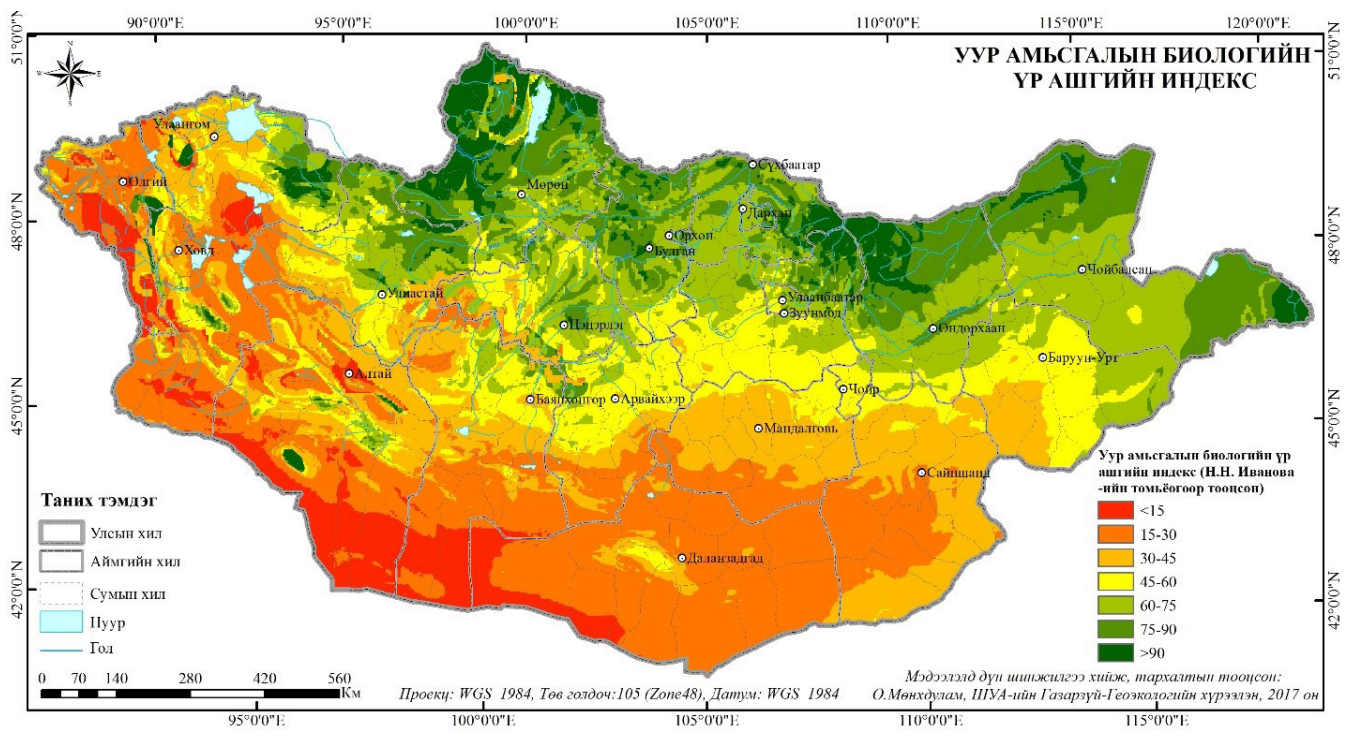

Зураг 2. Уур амьсгальн биологийн ур ашгийн индексийн орон зайн тархалт

ХУснэгт 2. Уур амьсгальн биологийн үр ашгийн индексийн орон зайн хуваарилалт (Н. Н.Иванова-ийн томьёогоор тооцсон Үр дүн)

\begin{tabular}{|c|c|c|}
\hline \multirow{2}{*}{ Уур амьсгалын биологийн үр ашгийн индекс } & \multicolumn{2}{|c|}{ Талбай } \\
\cline { 2 - 3 } & км $^{2}$ & $\%$ \\
\hline$<15$ & 91650.1 & 5.9 \\
\hline $15-30$ & 385977.4 & 24.6 \\
\hline $30-45$ & 294578.4 & 18.8 \\
\hline $45-60$ & 228776.9 & 14.6 \\
\hline $60-75$ & 283878.1 & 18.1 \\
\hline $75-90$ & 201436.3 & 12.9 \\
\hline$>90$ & 79702.8 & 5.1 \\
\hline
\end{tabular}

Д.И.Шашко (2005)-ийн боловсруулсан био-уур амьсгалын чадавхийн томьёо (5)оор тооцоо хийж үзэхэд Монгол орны нийт нутаг дэвсгэрийн 7.1\% нь хэт хуурайдулаан, $22.2 \%$ нь хуурай-дулаан, 16.2\% нь гандуу дулаан, 14.9\% нь чийг дутмагдулаан, $12.1 \%$ нь чийглэг-дулаан, $17.8 \%$ нь чийглэг сэрүүн, 9.7\% нь хэт чийглэгсэрүүн гэсэн ангилалд тус тус хамрагдаж байна (Хүснэгт 3, Зураг 3). 


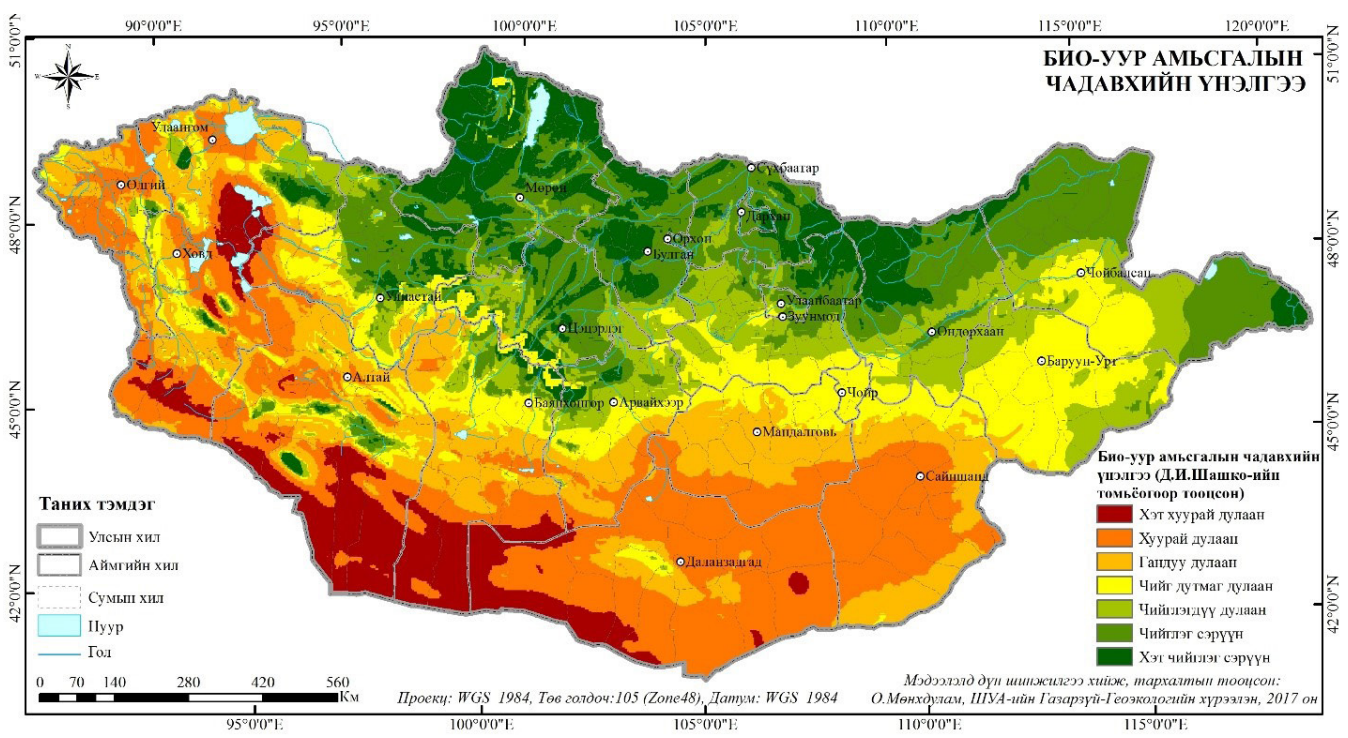

Зураг 3. Био-уур амьсгальын чадавхийн үнэлгээ

Хүснэгт 3. Био-уур амьсгалын чадавхийн үнэлгээ

(Д.И.Шаико-ийн томьёогоор тооцсон үр дүн)

\begin{tabular}{|c|c|c|}
\hline \multirow{2}{*}{ Био-уур амьсгалын чадавхийн үнэлгээ } & \multicolumn{2}{|c|}{ Талбай } \\
\cline { 2 - 3 } & км $^{2}$ & $\%$ \\
\hline Хэт хуурай- дулаан & 110918.9 & 7.1 \\
\hline Хуурай- дулаан & 348194.1 & 22.2 \\
\hline Гандуу- дулаан & 253954.8 & 16.2 \\
\hline Чийг дутмаг- дулаан & 233078.2 & 14.9 \\
\hline Чийглэгдүү-дулаан & 188773.0 & 12.1 \\
\hline Чийглэг- сэрүүн & 278610.9 & 17.8 \\
\hline Хэт чийглэг- сэрүүн & 152470.1 & 9.7 \\
\hline
\end{tabular}

Дээр дурдсан 3 арга зүйд үндэслэн сумдын чийг-дулааны коэффициент болон уур амьсгалын биологийн үр ашгийн индексийн 15 жилийн дунджийг тооцож Хүснэгт 4-д үзҮүлэв.

Хүснэгт 4. Хиймэл дагуулын мэдээ ашиглан тооцсон чийг-дулааны коэффициент болон уур амьсгалын биологийн үр ашгийн индекс, сумдаар (15 жилийн дундаж)

\begin{tabular}{|l|l|c|c|c|l|l|c|c|c|}
\hline Аймгийн нэр & Сумын нэр & ЧДК & КУ & БҮАИ & Аймгийн нэр & Сумын нэр & ЧДК & КУ & БҮАИ \\
\hline Архангай & Батцэнгэл & 2.18 & 0.50 & 75.46 & Өвөрхангай & Зүүнбаян-Улаан & 2.26 & 0.42 & 50.15 \\
\hline Архангай & Жаргалант & 2.86 & 0.62 & 74.86 & Өвөрхангай & Гучин-Ус & 1.16 & 0.28 & 49.98 \\
\hline Архангай & Цэцэрлэг & 2.82 & 0.61 & 73.76 & Өвөрхангай & Тарагт & 2.24 & 0.41 & 49.52 \\
\hline Архангай & Хайрхан & 2.03 & 0.47 & 70.36 & Өверхангай & Бүрд & 2.19 & 0.40 & 48.42 \\
\hline Архангай & Цахир & 2.99 & 0.77 & 69.31 & Өвөрхангай & Арвайхээр & 1.99 & 0.37 & 44.06 \\
\hline Архангай & Цэцэрлэг & 3.11 & 0.57 & 68.85 & Өверхангай & Нарийнтээл & 1.97 & 0.36 & 43.54 \\
\hline
\end{tabular}




\begin{tabular}{|c|c|c|c|c|c|c|c|c|c|}
\hline Архангай & Хотонт & 1.98 & 0.46 & 68.71 & Өвөрхангай & Сант & 1.35 & 0.27 & 40.63 \\
\hline Архангай & Өлзийт & 1.98 & 0.46 & 68.67 & Өвөрхангай & Төгрөг & 0.86 & 0.21 & 36.94 \\
\hline Архангай & Ихтамир & 3.06 & 0.56 & 67.68 & Өвөрхангай & Баянгол & 1.01 & 0.20 & 30.38 \\
\hline Архангай & Өгийнуур & 1.92 & 0.44 & 66.55 & Өвөрхангай & Баруунбаян-Улаан & 0.68 & 0.14 & 25.74 \\
\hline Архангай & Цэнхэр & 2.90 & 0.54 & 64.33 & Өвөрхангай & Богд & 0.89 & 0.16 & 23.65 \\
\hline Архангай & Төвшрүүлэх & 2.86 & 0.53 & 63.33 & Өмнөговь & Баяндалай & 0.86 & 0.16 & 29.22 \\
\hline Архангай & Хашаат & 1.73 & 0.40 & 59.97 & Өмнөговь & Мандал-Овоо & 0.56 & 0.14 & 29.15 \\
\hline Архангай & Эрдэнэмандал & 2.59 & 0.48 & 57.29 & Өмнөговь & Хүрмэн & 0.76 & 0.16 & 28.87 \\
\hline Архангай & Өндөр-Улаан & 2.18 & 0.47 & 56.98 & Өмнөговь & Ханхонгор & 0.67 & 0.14 & 25.72 \\
\hline Архангай & Хангай & 2.78 & 0.56 & 50.09 & Өмнөговь & Номгон & 0.67 & 0.14 & 25.53 \\
\hline Архангай & Чулуут & 2.68 & 0.54 & 48.20 & Өмнөговь & Булган & 0.55 & 0.12 & 25.52 \\
\hline Архангай & Булган & 3.82 & 0.53 & 47.61 & Өмнөговь & Сэврэй & 0.63 & 0.13 & 24.13 \\
\hline Архангай & Тариат & 2.79 & 0.46 & 41.04 & Өмнөговь & Цогт-Цэций & 0.63 & 0.13 & 24.02 \\
\hline Баян-Өлгий & Баяннуур & 0.75 & 0.25 & 37.63 & Өмнөговь & Манлай & 0.63 & 0.13 & 23.83 \\
\hline Баян-Өлгий & Дэлүүн & 0.83 & 0.29 & 34.28 & Өмнөговь & Цогт-Овоо & 0.45 & 0.11 & 23.54 \\
\hline Баян-Өлгий & Цагааннуур & 1.23 & 0.32 & 28.45 & Өмнөговь & Ноён & 0.60 & 0.13 & 22.99 \\
\hline Баян-Өлгий & Алтанцөгц & 0.51 & 0.17 & 25.48 & Өмнөговь & Баян-Овоо & 0.47 & 0.10 & 21.62 \\
\hline Баян-Өлгий & Толбо & 0.79 & 0.21 & 25.33 & Өмнөговь & Гурвантэс & 0.52 & 0.11 & 19.77 \\
\hline Баян-Өлгий & Цэнгэл & 0.76 & 0.17 & 20.03 & Өмнөговь & Ханбогд & 0.38 & 0.08 & 17.73 \\
\hline Баян-Өлгий & Сагсай & 0.75 & 0.16 & 19.58 & Сүхбаатар & Түмэнцогт & 1.51 & 0.36 & 65.16 \\
\hline Баян-Өлгий & Ногооннуур & 0.47 & 0.13 & 19.37 & Сүхбаатар & Мөнххаан & 1.79 & 0.41 & 61.84 \\
\hline Баян-Өлгий & Улаанхус & 0.73 & 0.16 & 19.21 & Сүхбаатар & Эрдэнэцагаан & 1.90 & 0.38 & 57.00 \\
\hline Баян-Өлгий & Өлгий & 0.71 & 0.15 & 18.51 & Сүхбаатар & Наран & 1.63 & 0.38 & 56.37 \\
\hline Баян-Өлгий & Булган & 2.53 & 0.29 & 11.57 & Сүхбаатар & Дарьганга & 1.62 & 0.37 & 56.15 \\
\hline Баян-Өлгий & Алтай & 2.55 & 0.23 & 9.07 & Сүхбаатар & Асгат & 1.22 & 0.29 & 52.83 \\
\hline Баян-Өлгий & Буянт & 2.34 & 0.17 & 6.81 & Сүхбаатар & Сүхбаатар & 1.20 & 0.29 & 51.75 \\
\hline Баянхонгор & Жаргалант & 1.92 & 0.51 & 61.30 & Сүхбаатар & Түвшинширээ & 1.55 & 0.31 & 46.58 \\
\hline Баянхонгор & Заг & 1.79 & 0.48 & 57.43 & Сүхбаатар & Уулбаян & 1.54 & 0.31 & 46.19 \\
\hline Баянхонгор & Эрдэнэцогт & 2.12 & 0.46 & 55.54 & Сүхбаатар & Онгон & 1.49 & 0.30 & 44.56 \\
\hline Баянхонгор & Баян-Овоо & 2.06 & 0.45 & 53.96 & Сүхбаатар & Халзан & 1.45 & 0.29 & 43.54 \\
\hline Баянхонгор & Бөмбөгөр & 1.92 & 0.42 & 50.19 & Сүхбаатар & Баяндэлгэр & 1.41 & 0.28 & 42.33 \\
\hline Баянхонгор & Бууцагаан & 1.22 & 0.33 & 49.97 & Сэлэнгэ & Алтанбулаг & 1.67 & 0.46 & 83.15 \\
\hline Баянхонгор & Галуут & 2.56 & 0.51 & 46.06 & Сэлэнгэ & Сүхбаатар & 1.66 & 0.46 & 82.87 \\
\hline Баянхонгор & Баянхонгор & 1.82 & 0.34 & 40.32 & Сэлэнгэ & Зүүнбүрэн & 1.64 & 0.45 & 81.72 \\
\hline Баянхонгор & Өлзийт & 1.79 & 0.33 & 39.71 & Сэлэнгэ & Шаамар & 1.61 & 0.45 & 80.31 \\
\hline Баянхонгор & Хүрээмарал & 1.46 & 0.32 & 38.30 & Сэлэнгэ & Epөө & 1.59 & 0.44 & 79.42 \\
\hline Баянхонгор & Баацагаан & 0.88 & 0.21 & 38.20 & Сэлэнгэ & Баянгол & 2.16 & 0.50 & 74.83 \\
\hline
\end{tabular}




\begin{tabular}{|c|c|c|c|c|c|c|c|c|c|}
\hline Баянхонгор & Жинст & 0.81 & 0.20 & 35.17 & Сэлэнгэ & Түшиг & 2.09 & 0.48 & 72.37 \\
\hline Баянхонгор & Гурванбулаг & 1.51 & 0.39 & 34.94 & Сэлэнгэ & Жавхлант & 2.07 & 0.48 & 71.59 \\
\hline Баянхонгор & Баянговь & 0.72 & 0.17 & 31.13 & Сэлэнгэ & Баруунбүрэн & 2.07 & 0.48 & 71.56 \\
\hline Баянхонгор & Баянцагаан & 0.85 & 0.20 & 29.47 & Сэлэнгэ & Цагааннуур & 2.04 & 0.47 & 70.68 \\
\hline Баянхонгор & Шинэжинст & 0.84 & 0.19 & 28.96 & Сэлэнгэ & Мандал & 2.04 & 0.47 & 70.47 \\
\hline Баянхонгор & Баян-Өндөр & 1.11 & 0.24 & 28.94 & Сэлэнгэ & Орхонтуул & 2.02 & 0.47 & 69.98 \\
\hline Баянхонгор & Богд & 0.67 & 0.14 & 25.63 & Сэлэнгэ & Хүдэр & 2.02 & 0.47 & 69.81 \\
\hline Баянхонгор & Баянлиг & 0.62 & 0.13 & 23.55 & Сэлэнгэ & Хушаат & 2.01 & 0.46 & 69.62 \\
\hline Баянхонгор & Баянбулаг & 1.29 & 0.26 & 23.18 & Сэлэнгэ & Сайхан & 2.01 & 0.46 & 69.44 \\
\hline Булган & Хишиг-Өндөр & 2.36 & 0.64 & 96.53 & Сэлэнгэ & Сант & 1.88 & 0.43 & 65.11 \\
\hline Булган & Сэлэнгэ & 1.71 & 0.47 & 85.18 & Сэлэнгэ & Орхон & 1.87 & 0.43 & 64.76 \\
\hline Булган & Хутаг-Өндөр & 2.39 & 0.55 & 82.60 & Төв & Мөнгөнморьт & 1.81 & 0.60 & 90.40 \\
\hline Булган & Бугат & 2.98 & 0.65 & 77.98 & Төв & Баяндэлгэр & 1.71 & 0.57 & 85.44 \\
\hline Булган & Бүрэгхангай & 2.23 & 0.51 & 77.09 & Төв & Сүмбэр & 2.10 & 0.48 & 72.60 \\
\hline Булган & Хангал & 2.18 & 0.50 & 75.57 & Төв & Эрдэнэ & 2.23 & 0.59 & 71.24 \\
\hline Булган & Тэшиг & 2.12 & 0.49 & 73.45 & Төв & Архуст & 1.70 & 0.46 & 69.45 \\
\hline Булган & Баян-Агт & 3.25 & 0.60 & 71.89 & Төв & Борнуур & 2.00 & 0.46 & 69.11 \\
\hline Булган & Могод & 2.68 & 0.58 & 70.12 & Төв & Баян & 1.69 & 0.46 & 69.08 \\
\hline Булган & Баяннуур & 1.53 & 0.37 & 65.96 & Төв & Жаргалант & 1.98 & 0.46 & 68.58 \\
\hline Булган & Сайхан & 2.86 & 0.53 & 63.29 & Төв & Зуунмод & 1.66 & 0.45 & 67.79 \\
\hline Булган & Орхон & 2.74 & 0.51 & 60.75 & Төв & Баянжаргалан & 1.64 & 0.45 & 67.20 \\
\hline Булган & Дашинчилэн & 1.83 & 0.37 & 54.80 & Төв & Баянчандмань & 1.93 & 0.44 & 66.73 \\
\hline Булган & Рашаант & 1.57 & 0.36 & 54.17 & Төв & Заамар & 1.91 & 0.44 & 66.00 \\
\hline Булган & Гурванбулаг & 1.69 & 0.34 & 50.73 & Төв & Цээл & 1.89 & 0.44 & 65.36 \\
\hline Говь-Алтай & Цогт & 1.96 & 0.43 & 51.30 & Төв & Баянцогт & 1.88 & 0.43 & 65.13 \\
\hline Говь-Алтай & Халиун & 0.73 & 0.31 & 47.06 & Төв & Угтаалцайдам & 1.88 & 0.43 & 65.05 \\
\hline Говь-Алтай & Дэлгэр & 1.24 & 0.29 & 42.94 & Төв & Баянхангай & 1.83 & 0.42 & 63.39 \\
\hline Говь-Алтай & Чандмань & 1.50 & 0.33 & 39.32 & Төв & Лүн & 1.78 & 0.41 & 61.76 \\
\hline Говь-Алтай & Баян-Уул & 1.05 & 0.24 & 36.50 & Төв & Аргалант & 1.68 & 0.39 & 58.17 \\
\hline Говь-Алтай & Төгрөг & 1.50 & 0.39 & 34.66 & Төв & Эрдэнэсант & 1.67 & 0.39 & 57.76 \\
\hline Говь-Алтай & Тайшир & 1.56 & 0.29 & 34.63 & Төв & Дэлгэрхаан & 1.61 & 0.37 & 55.78 \\
\hline Говь-Алтай & Цээл & 1.54 & 0.28 & 34.05 & Төв & Алтанбулаг & 1.51 & 0.35 & 52.40 \\
\hline Говь-Алтай & Эрдэнэ & 1.24 & 0.27 & 32.53 & Төв & Баян-Өнжүүл & 1.50 & 0.35 & 52.06 \\
\hline Говь-Алтай & Жаргалан & 0.90 & 0.21 & 31.18 & Төв & Баянцагаан & 1.47 & 0.34 & 50.72 \\
\hline Говь-Алтай & Бигэр & 0.53 & 0.15 & 26.46 & Төв & Өндөрширээт & 1.69 & 0.34 & 50.63 \\
\hline Говь-Алтай & Шарга & 0.68 & 0.14 & 25.86 & Төв & Бүрэн & 1.53 & 0.31 & 45.88 \\
\hline Говь-Алтай & Бугат & 1.98 & 0.27 & 24.64 & Төв & Батсүмбэр & 2.05 & 0.38 & 45.38 \\
\hline
\end{tabular}




\begin{tabular}{|c|c|c|c|c|c|c|c|c|c|}
\hline Говь-Алтай & Дарви & 0.67 & 0.16 & 23.27 & 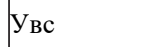 & Баруунтуруун & 1.35 & 0.69 & \#\#\#\# \\
\hline Говь-Алтай & Алтай & 0.39 & 0.08 & 14.70 & $\mathrm{y}_{\mathrm{Bc}}$ & Цагаанхайрхан & 4.28 & 1.10 & 98.95 \\
\hline Говь-Алтай & Алтай & 4.86 & 0.35 & 14.15 & $\mathrm{У}_{\text {вс }}$ & Өндөрхангай & 1.67 & 0.80 & 96.32 \\
\hline Говь-Алтай & Тонхил & 2.83 & 0.17 & 6.97 & $\mathrm{У}_{\text {вс }}$ & Хяргас & 1.41 & 0.61 & 90.75 \\
\hline Говьсүмбэр & Баянтал & 1.12 & 0.31 & 55.95 & 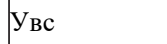 & Зүүнхангай & 1.89 & 0.65 & 77.72 \\
\hline Говьсүмбэр & Шивээговь & 1.11 & 0.27 & 48.11 & $\mathrm{У}_{\text {вс }}$ & Зүүнговь & 1.01 & 0.40 & 72.39 \\
\hline Говьсүмбэр & Хөхморьт & 0.63 & 0.17 & 31.25 & $\mathrm{У}_{\text {вс }}$ & Тэс & 0.84 & 0.34 & 60.77 \\
\hline Дархан-Уул & Шарынгол & 2.09 & 0.57 & 85.57 & 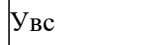 & малчин & 0.94 & 0.31 & 47.03 \\
\hline Дархан-Уул & Орхон & 2.01 & 0.46 & 69.74 & $\mathrm{y}_{\mathrm{Bc}}$ & Түргэн & 0.64 & 0.25 & 45.84 \\
\hline Дорноговь & Иххэт & 1.19 & 0.29 & 51.59 & $\mathrm{У}_{\text {вс }}$ & Давст & 0.75 & 0.24 & 44.07 \\
\hline Дорноговь & Дэлгэрэх & 1.02 & 0.24 & 44.10 & $\mathrm{y}_{\text {вс }}$ & Өлгий & 0.81 & 0.27 & 40.56 \\
\hline Дорноговь & Даланжаргалан & 1.00 & 0.24 & 43.14 & $\mathrm{У}_{\text {вс }}$ & Ховд & 0.80 & 0.27 & 40.19 \\
\hline Дорноговь & Алтанширээ & 0.73 & 0.20 & 42.82 & 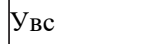 & Өмнөговь & 0.79 & 0.26 & 39.73 \\
\hline Дорноговь & Айраг & 0.99 & 0.24 & 42.67 & 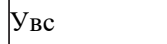 & Хархираа & 0.63 & 0.21 & 37.39 \\
\hline Дорноговь & Эрдэнэ & 0.71 & 0.18 & 36.91 & $\mathrm{y}_{\mathrm{Bc}}$ & Тариалан & 1.12 & 0.30 & 35.74 \\
\hline Дорноговь & Хатанбулаг & 0.67 & 0.16 & 34.64 & $\mathrm{У}_{\mathrm{Bc}}$ & Сагил & 0.60 & 0.20 & 35.24 \\
\hline Дорноговь & Өргөн & 0.65 & 0.16 & 33.59 & $\mathrm{y}_{\text {вс }}$ & Улаангом & 0.59 & 0.19 & 34.72 \\
\hline Дорноговь & Замын-Үүд & 0.62 & 0.15 & 31.97 & $\mathrm{У}_{\text {вс }}$ & Наранбулаг & 0.46 & 0.15 & 27.29 \\
\hline Дорноговь & Улаанбадрах & 0.56 & 0.14 & 29.17 & $\mathrm{У}_{\mathrm{Bc}}$ & Бөхмөрөн & 0.47 & 0.13 & 19.27 \\
\hline Дорноговь & Сайхандулаан & 0.63 & 0.15 & 27.06 & $\mathrm{У}_{\text {вс }}$ & Завхан & 0.18 & 0.06 & 10.86 \\
\hline Дорноговь & Мандах & 0.51 & 0.12 & 22.25 & Улаанбаатар & Багануур & 1.74 & 0.47 & 71.05 \\
\hline Дорноговь & Хөвсгөл & 0.47 & 0.10 & 21.80 & Улаанбаатар & Налайх & 1.67 & 0.45 & 68.15 \\
\hline Дорнод & Гурванзагал & 1.77 & 0.49 & 88.47 & Улаанбаатар & Улаанбаатар & 1.72 & 0.40 & 59.69 \\
\hline Дорнод & Чулуунхороот & 1.71 & 0.47 & 85.46 & Ховд & Дуут & 1.04 & 0.36 & 42.91 \\
\hline Дорнод & Баяндун & 2.34 & 0.54 & 80.94 & Ховд & Мөнххайрхан & 0.95 & 0.33 & 39.15 \\
\hline Дорнод & Баян-Уул & 2.30 & 0.53 & 79.50 & Ховд & Ховд & 0.91 & 0.25 & 37.41 \\
\hline Дорнод & Халхгол & 1.56 & 0.43 & 77.59 & Ховд & Чандмань & 0.57 & 0.25 & 36.85 \\
\hline Дорнод & Дашбалбар & 2.20 & 0.51 & 76.26 & Ховд & Мөст & 0.77 & 0.18 & 26.83 \\
\hline Дорнод & Цагаан-Овоо & 1.68 & 0.40 & 72.48 & Ховд & Жаргалант & 0.73 & 0.17 & 25.36 \\
\hline Дорнод & Сэргэлэн & 1.57 & 0.38 & 67.74 & Ховд & Манхан & 0.72 & 0.17 & 24.92 \\
\hline Дорнод & Хөлөнбуйр & 1.52 & 0.37 & 65.82 & Ховд & Мянгад & 0.47 & 0.13 & 23.65 \\
\hline Дорнод & Чойбалсан & 1.50 & 0.36 & 64.88 & Ховд & Эрдэнэбүрэн & 0.47 & 0.13 & 23.57 \\
\hline Дорнод & Булган & 1.47 & 0.35 & 63.65 & Ховд & Буянт & 0.47 & 0.13 & 23.27 \\
\hline Дорнод & Матад & 1.46 & 0.35 & 63.27 & Ховд & Дарви & 0.64 & 0.15 & 22.19 \\
\hline Дорнод & Баянтүмэн & 1.45 & 0.35 & 62.47 & Ховд & Цэцэг & 0.62 & 0.14 & 21.54 \\
\hline Дундговь & Цагаандэлгэр & 1.35 & 0.31 & 46.88 & Ховд & Булган & 0.41 & 0.11 & 20.26 \\
\hline Дундговь & Адаацаг & 1.33 & 0.31 & 46.05 & Ховд & Үенч & 0.38 & 0.11 & 19.14 \\
\hline
\end{tabular}




\begin{tabular}{|c|c|c|c|c|c|c|c|c|c|}
\hline Дундговь & Баянжаргалан & 0.99 & 0.24 & 42.63 & Ховд & Зэрэг & 0.38 & 0.10 & 18.85 \\
\hline Дундговь & Дэлгэрцогт & 0.96 & 0.23 & 41.43 & Ховд & Дөргөн & 0.33 & 0.09 & 16.52 \\
\hline Дундговь & Сайнцагаан & 0.95 & 0.23 & 41.04 & Ховд & Алтай & 0.35 & 0.08 & 15.07 \\
\hline Дундговь & Дэрэн & 0.95 & 0.23 & 40.99 & Хөвсгөл & Цэцэрлэг & 2.01 & 0.96 & 97.00 \\
\hline Дундговь & Эрдэнэдалай & 0.95 & 0.23 & 40.87 & Хөвсгөл & Арбулаг & 2.53 & 0.87 & 97.00 \\
\hline Дундговь & Луус & 0.94 & 0.23 & 40.54 & Хөвсгөл & Улаан-Уул & 2.35 & 0.81 & 96.80 \\
\hline Дундговь & Гурьансайхан & 0.92 & 0.22 & 39.72 & Хөвсгөл & Баянзүрх & 2.33 & 0.80 & 95.98 \\
\hline Дундговь & Говь-Угтаал & 1.26 & 0.25 & 37.91 & Хөвсгөл & Бүрэнтогтох & 1.85 & 0.62 & 92.63 \\
\hline Дундговь & Дэлгэрхангай & 0.82 & 0.20 & 35.22 & Хөвсгөл & Цагаан-Уул & 2.16 & 0.74 & 88.80 \\
\hline Дундговь & Өндөршил & 0.80 & 0.19 & 34.72 & Хөвсгөл & Цагааннуур & 2.14 & 0.74 & 88.23 \\
\hline Дундговь & Хулд & 0.76 & 0.18 & 32.67 & Хөвсгөл & Рэнчинлхүмбэ & 2.08 & 0.71 & 85.72 \\
\hline Дундговь & Өлзийт & 0.76 & 0.16 & 28.80 & Хөвсгөл & Шинэ-Идэр & 2.48 & 0.66 & 79.25 \\
\hline Дундговь & Сайхан-Овоо & 0.62 & 0.15 & 26.65 & Хөвсгөл & Хатгал & 2.43 & 0.65 & 77.88 \\
\hline Завхан & Идэр & 2.05 & 0.70 & 84.52 & Хөвсгөл & Алаг-Эрдэнэ & 2.38 & 0.63 & 76.10 \\
\hline Завхан & Тосонцэнгэл & 1.93 & 0.66 & 79.49 & Хөвсгөл & Ханх & 3.08 & 0.79 & 71.32 \\
\hline Завхан & Тэс & 1.22 & 0.52 & 78.64 & Хөвсгөл & Тариалан & 2.06 & 0.48 & 71.31 \\
\hline Завхан & Нөмрөг & 1.88 & 0.64 & 77.21 & Хөвсгөл & Эрдэнэбулган & 2.03 & 0.47 & 70.17 \\
\hline Завхан & Тэлмэн & 1.87 & 0.64 & 77.07 & Хөвсгөл & Их-Уул & 2.00 & 0.46 & 69.33 \\
\hline Завхан & Асгат & 1.86 & 0.64 & 76.45 & Хөвсгөл & Жаргалант & 2.14 & 0.57 & 68.35 \\
\hline Завхан & Их-Уул & 1.84 & 0.63 & 75.67 & Хөвсгөл & Тосонцэнгэл & 1.96 & 0.45 & 67.97 \\
\hline Завхан & Сонгино & 1.80 & 0.62 & 74.04 & Хөвсгөл & Цагаан-Үүр & 1.92 & 0.44 & 66.53 \\
\hline Завхан & Баянтэс & 1.60 & 0.55 & 65.68 & Хөвсгөл & Түнэл & 2.53 & 0.55 & 66.28 \\
\hline Завхан & Яруу & 2.81 & 0.72 & 64.98 & Хөвсгөл & Рашаант & 2.85 & 0.53 & 63.15 \\
\hline Завхан & Цэцэн-Уул & 2.57 & 0.66 & 59.48 & Хөвсгөл & Галт & 2.40 & 0.52 & 62.92 \\
\hline Завхан & Баянхайрхан & 2.49 & 0.64 & 57.72 & Хөвсгөл & Чандмань-Өндөр & 2.39 & 0.52 & 62.45 \\
\hline Завхан & Эрдэнэхайрхан & 1.79 & 0.48 & 57.19 & Хөвсгөл & Төмөрбулаг & 2.31 & 0.50 & 60.51 \\
\hline Завхан & Сантмаргац & 1.12 & 0.37 & 56.00 & Хөвсгөл & Мөрөн & 1.73 & 0.40 & 60.01 \\
\hline Завхан & Цагаанчулуут & 2.10 & 0.46 & 55.02 & Хэнтий & Батширээт & 2.34 & 0.64 & 95.90 \\
\hline Завхан & Түдэвтэй & 2.34 & 0.60 & 54.12 & Хэнтий & Өмнөдэлгэр & 2.09 & 0.57 & 85.31 \\
\hline Завхан & Цагаанхайрхан & 1.99 & 0.43 & 52.19 & Хэнтий & Дадал & 2.39 & 0.55 & 82.72 \\
\hline Завхан & Улиастай & 1.90 & 0.42 & 49.81 & Хэнтий & Биндэр & 2.33 & 0.54 & 80.54 \\
\hline Завхан & Шилүүстэй & 1.82 & 0.40 & 47.52 & Хэнтий & Баян-Адарга & 2.29 & 0.53 & 79.35 \\
\hline Завхан & Алдархаан & 1.73 & 0.38 & 45.36 & Хэнтий & Цэнхэрмандал & 1.93 & 0.53 & 79.08 \\
\hline Завхан & Отгон & 0.97 & 0.33 & 39.77 & Хэнтий & Норовлин & 2.26 & 0.52 & 78.23 \\
\hline Завхан & Завханмандал & 0.88 & 0.24 & 35.85 & Хэнтий & Жаргалтхаан & 1.89 & 0.51 & 77.22 \\
\hline Завхан & Дөрвөлжин & 0.59 & 0.16 & 29.64 & Хэнтий & Баянмөнх & 1.40 & 0.39 & 69.94 \\
\hline Завхан & Ургамал & 0.72 & 0.20 & 29.63 & Хэнтий & Бэрх уурхай & 2.01 & 0.46 & 69.59 \\
\hline
\end{tabular}




\begin{tabular}{|l|l|l|l|l|l|l|l|l|l|}
\hline Орхон-Уул & Жаргалант & 2.16 & 0.50 & 74.60 & Хэнтий & Өндөрхаан & 1.93 & 0.45 & 66.98 \\
\hline Өвөрхангай & Хархиорин & 1.99 & 0.46 & 68.97 & Хэнтий & Батноров & 1.93 & 0.44 & 66.73 \\
\hline Өвөрхангай & Хайрхандулаан & 1.78 & 0.41 & 61.77 & Хэнтий & Мөрөн & 1.91 & 0.44 & 66.02 \\
\hline Өвөрхангай & Хужирт & 2.68 & 0.49 & 59.36 & Хэнтий & Баян-Овоо & 1.51 & 0.36 & 65.14 \\
\hline Өвөрхангай & Бат-Өлзий & 2.64 & 0.49 & 58.58 & Хэнтий & Хэрлэн & 1.88 & 0.43 & 65.08 \\
\hline Өвөрхангай & Баян-Өндөр & 1.68 & 0.39 & 58.00 & Хэнтий & Бор-Өндөр & 1.20 & 0.33 & 59.87 \\
\hline Өвөрхангай & Зүйл & 2.53 & 0.47 & 56.07 & Хэнтий & Дэлгэрхаан & 1.71 & 0.40 & 59.35 \\
\hline Өвөрхангай & Уянга & 2.40 & 0.44 & 53.06 & Хэнтий & Дархан & 1.64 & 0.38 & 56.73 \\
\hline Өвөрхангай & Өлзийт & 2.36 & 0.44 & 52.23 & Хэнтий & Галшар & 1.23 & 0.30 & 53.16 \\
\hline
\end{tabular}

\section{ДҮГНЭЛТ}

Судалгаагаар хиймэл дагуулын мэдээ болон цаг уурын станц, харуулын мэдээнд үндэслэн био-уур амьсгалын чадавхийг үнэлэх арга зүй, орон зайн тархалтын зураглал үйлдэх аргачлалыг хөндлөө.

Судалгаанд Г.Т. Селянинова (1937)-ийн боловсруулсан чийг-дулааны коэффициент, Н.Н. Иванова (1999)-ийн боловсруулсан уур амьсгалын биологийн үр ашгийн индекс, Д.И. Шашко (2005)-ийн боловсруулсан био-уур амьсгалын чадавхийн үнэлгээний индекс зэрэг арга зүйг сонгон ашигласан.

Газарзүйн ялгаатай байршил дахь цаг уурын станцын 2000-2014 оны сарын дундаж агаарын температурын мэдээ, мөн хугацааны MODIS хиймэл дагуулын гадаргын температур, ууршилт, TRMM хиймэл дагуулын хур тунадасны мэдээг тус тус ашигласан.

Цаг уурын станц, харуул дээр бүртгэгдсэн мэдээ нь олон тооны харилцан уялдаа бүхий багаж, нэгдсэн арга зүйг ашигладаг тул био- уур амьсгалын загваруудад ашиглах мэдээллийг олж авах үндэслэл болсон.

Нөгөө талаас, эрс тэс уур амьсгалтай, цаг уурын элементүүд нь богино зайд хувьсан өөрчлөгддөг манай орны хувьд өөр хоорондоо алслагдсан 300 гаруй станц, харуулын хэмжилтийн цэгийн хүрээнд орон зайн ялгаатай био-уур амьсгалын чадавхийн үнэлгээний зураг гаргахад төдийлөн хангалттай биш учир хиймэл дагуулын мэдээг ашигласан. Судалгааны талбайн хамрах хүрээ, нарийвчлал, цаг хугацааны давтамжийн онцлогоос хамаарч MODIS болон TRMM хиймэл дагуулын мэдээг ашиглав.

Дээр дурдсан арга зүй, мэдээ, мэдээллийг ашиглан дараах 3 үзүүлэлтийг тооцож орон зайн тархалтыг зураглал үйлдэв. Үүнд:

Чийг- дулааны коэффициентийн хувьд Монгол орны нутаг дэвсгэрийн 7.1\% нь хэт хуурай, 20\% нь хуурай, $12.1 \%$ нь гандуу, 14.4\% нь чийг дутмаг, 18.8\% нь чийг хүрэлцээтэй, $12 \%$ нь чийглэг, $15.6 \%$ нь илүүдэл чийгтэй гэсэн ангилалд тус тус хамрагдаж байна.

Уур амьсгалын биологийн үр ашгийн индексийн хувьд Монгол орны нийт нутаг дэвсгэрийн 5.9\% нь 15 хувиас бага, 24.6\% нь $15-30$ хувийн, $18.8 \%$ нь $30-45$ хувийн, $14.6 \%$ нь 45-60 хувийн, $18.1 \%$ нь $60-75$ хувийн, $12.9 \%$ нь 75-90 хувийн, 5.1\% нь 90ээс дээш хувийн бүтээмжтэй гэсэн тооцоо гарч байна.

Био-уур амьсгалын чадавхийн үнэлгээний үр дүнгээр нийт нутаг дэвсгэрийн $7.1 \%$ нь хэт хуурай-дулаан, $22.2 \%$ нь хуурай-дулаан, 16.2\% нь гандуу дулаан, $14.9 \%$ нь чийг дутмаг-дулаан, $12.1 \%$ нь чийглэг-дулаан, $17.8 \%$ нь чийглэг сэрүүн, 9.7\% нь хэт чийглэг- сэрүүн гэсэн ангилалд тус тус хамрагдаж байна.

Судалгааны үр дүнгээс үзэхэд дэлхийн ажиглалтын хиймэл дагуулын мэдээ болон 
газарзүйн мэдээллийн систем, тандан судалгааны технологийг ашиглан био- уур амьсгалын үндсэн хүчин зүйлүүд болох чийг- дулааны коэффициент, уур амьсгалын биологийн индекс, био-уур амьсгалын чадавхийн индекс зэрэг хүчин зүйлүүдийг тооцож, орон зайн тархалтын зураглал үйлдэх боломжтой гэсэн дүгнэлтэд хүрлээ.

Сонгон авсан 3 арга зүйн дагуу орон зайн тархалтын зураглал боловсруулснаар бүс нутгийн түвшний асуудлыг уур амьсгалын хандлагын үүднээс зөв ялган тогтоох боломжтойг илтгэх ба байгаль, цаг уурын нөхцлөөс шууд хамааралтай манай орны нийгэм- эдийн засгийн гол салбар болох хүн ам, мал аж ахуй, газар тариалангийн салбарын төлөвлөлт, менежментийн үйл ажиллагаа зохион байгуулахад цаг хугацаа хэмнэсэн, шинжлэх ухааны үндэслэлтэй шийдвэр гаргах боломж бүрдэж байна. Цаашид оролтын мэдээний нарийвчлалыг сайжруулж орон нутгийн төлөвлөлт, менежментийн үйл ажиллагаа зохион байгуулахад ашиглах боломжтой.

\section{Талархал}

ЭнэхүҮ судалгааны ажлыг Шинжлэх ухаан технологийн сангийн санхүүжилтээр ШУА-ийн ГГХ-ийн Физик газарзүйн салбарт хэрэгжиж буй “Монгол орны байгалийн бүсүүдийн ландшафтын экологийн чадавхийн үнэлгээ” төслийн хүрээнд гүйцэтгэсэн, судалгааг амжилттай хэрэгжүүлэхэд шууд болон дам байдлаар тусалсан төслийн удирдагч болон Физик газарзүйн салбарынхаа хамт олонд талархал илэрхийлье. Мөн цаг уурын станц, харуулын бодит хэмжилтийн мэдээллээр хангасан Ус цаг уур, орчны судалгаа, мэдээллийн хүрээлэнгийн хамт олон болон судалгааны ажлын анхдагч хувилбарт үнэ цэнэтэй санал өгсөнд талархал илэрхийлье.

\section{НОМ ЗУЙ}

[1] БНМАУ-ын газрын судалбарын мужлалт ба тариаланд тохиромжтой эдэлбэр газрын чанарын үнэлгээ. (1983). Улаанбаатар.[2] Башалхнов, И.А., Намхайжанцан, Г. (2015). Уур амьсгалын тааламжгүй байдал. Байгал нуурын сав газрын экологийн атлас, Улаанбаатар, ху 26-27.[3] Селянинов, Г.Т. (1937). Мировой агроклиматической справочник/ред, С.411.

[4] Иванов, Н.Н. (1999). Показатель биологической эффективности климата. География, 3, , С.91-98.

[5] Баярмаа. В. (2015). Агроклиматические ресурсы и их влияние на урожайность (Западные сомоны Сэлэнгийского аймака, Монголия), Науки о Земле, 399, С.241246. DOI:10.17223/15617793/399/39

[6] Encyclopedia of climate resources of the Russian Federation. (2005). St.-Petersburg, p320.

[7] Mejía, D. (2014). Bioclimate Atlas of Jalisco State Mexico, Energy Procedia. Elsevier p2033-2041. doi: 10.1016/j.egypro.2014.10.168.[8] Гансүх, Я., Жамбалжав, Я. (2015). MODIS хиймэл дагуулын гадаргын температурын мэдээг боловсруулах арга зүй. Геологи-Газарзүйн салбарын залуу эрдэмтэн, багш судлаачдын эрдэм шинжилгээний бага хурал “Хүрэл Тогоот-2015” хурлын эмхтгэл, Улаанбаатар, Монгол, ху 29-39.

[9] Auliciems, A. (1990). Psychophysiological criteria for global zones of building design. Proceedings 9th International Society of Biometeorology Conference. Part 2. Biometeorology, 8, p 69-86.

[10] Olgyay.V. (1963). Design with climate. Princeton University Press, Princeton. p190

[11] Benali, A., Carvalho, A. C., Nunes, J. P., Carvalhais, N., \& Santos, A. (2012). Remote Sensing of Environment Estimating air surface temperature in Portugal using MODIS 
LST data. Remote Sensing of Environment, 124, 108-121. https://doi.org/10.1016/j. rse.2012.04.024

[12] Colombi, A., Michele, C. De, Pepe, M., \& Rampini, A. (2007). ESTIMATION OF DAILY MEAN AIR TEMPERATURE, (3), 38-46.

[13] Gregory, G., Goddard, N., Sciences, E., Data, G. E. S., \& Services, I. (2009). Estimation of Surface Air Temperature from MODIS $1 \mathrm{~km}$ Resolution Land Surface Temperature over Northern China Suhung Abstract : Leptoukh, 2008, 2009.

[14] Liu, S., Su, H., Zhang, R., Tian, J., \& Wang, W. (2016). Estimating the Surface Air Temperature by Remote Sensing in Northwest China Using an Improved AdvectionEnergy Balance for Air Temperature Model, 2016.

[15] Yang, Y. Z., Cai, W. H., \& Yang, J. (2017). Evaluation of MODIS Land Surface Temperature Data to Estimate Near-Surface Air Temperature in, 1-19. https://doi. org $/ 10.3390 /$ rs 9050410

[16] Zeng, L., Wardlow, B. D., Tadesse, T., Shan, J., Hayes, M. J., Li, D., \& Xiang, D. (2015). Estimation of Daily Air Temperature Based on MODIS Land Surface Temperature Products over the Corn Belt in the US, 951-970. https://doi.org/10.3390/rs70100951 


\title{
ASSESSMENT BIOCLIMATE POTENTIAL OF MONGOLIA BASED ON THE SATELLITE IMAGE AND METEOROLOGICAL OBSERVATION DATA
}

\author{
Munkhdulam. O' ${ }^{1 *}$ Avirmed. $E^{1}$, Sainbayar. $D^{1}$ \\ ${ }^{I}$ Institute of Geography and Geoecology, Mongolian Academy of Sciences \\ *corresponding author, e-mail: munkhdulamo@gmail.com
}

\begin{abstract}
The purpose of this study was to assess bioclimate potential of Mongolia based on the satellite image and meteorological observation data. In this research were applied hydrothermal coefficient, biological effectiveness index, bioclimatic potential coefficient that Selyaninov, Ivanov and Shashko developed formula, respectively. The analysis used time series MODIS (Moderate Resolution Imaging Spectroradiometer) products (MOD 11, MOD16) averaged over 16 days from January to December 2000-2014 with a resolution of $1 \mathrm{~km}$, monthly rainfall data 2000-2014 from TRMM (Tropical Rainfall Measure Mission) satellite with a resolution of 0.25 degree and monthly air temperature and lack of moisture data 2000-2014 from Meteorological station. We generated spatial distribution maps hydrothermal coefficient, biological effectiveness index, and bio-climate potential of Mongolia. As shown in the results evaluation bio-climate potential is possible using GIS and remote sensing technology based on a satellite imagery and meteorological data. The above mentioned 3 formulas evaluation for bioclimate potential can be used to save time planning and management for climate assessment and it allows for the possibility of justifying policy decisions with science.
\end{abstract}

Key words: Hydrothermal coefficient, biological effectiveness index, bio-climatic potential, satellite imagery; 